\title{
Haematological Changes Induced by Municipal Solid Waste in Wild Rats (Rattus rattus)
}

\author{
Adewumi O. O. ${ }^{1, *}$, Oladele E. O. ${ }^{1}$ and Taiwo I. A. ${ }^{2}$ \\ ${ }^{1}$ Biology Unit, Distance Learning Institute, University of Lagos, Akoka, Lagos State, Nigeria \\ ${ }^{2}$ Department of Cell Biology and Genetics, University of Lagos, Akoka, Lagos State, Nigeria \\ Corresponding Author: *oluadewumi@unilag.edu.ng
}

\begin{abstract}
The effect of the exposure of landfill pollutants on haematology, body and organ weights of Rattus rattus was investigated. The potential hazards of this landfill on the haematology of the exposed rats were investigated. Weights of rats in the control group (232.6g) were significantly higher $(p<0.05)$ than the exposed wild rats $(167.6 \mathrm{~g})$. The Packed Cell Volume, PCV (\%) of rats exposed to landfill pollutants was found to be $32.0 \pm 13.9$ while that of control rat was $43.4 \pm 4.7$. Haemoglobin $(\mathrm{g} / \mathrm{dl})$ of control rats was observed to be $14.2 \pm 1.2$ while that of exposed rats was $10.0 \pm 4.1$. The constituents of the municipal waste especially heavy metals probably aggravated the observed changes in the blood parameters. The experimental results indicated that exposure to landfill pollutants may lead to ill health particularly anaemia. Also, exposure to municipal solid waste landfill may induce haematological alterations in humans as evident in the wild rats studied.
\end{abstract}

Keywords: Landfill, Solid waste, Haematology, Hazards, Environmental Pollution

\subsection{Introduction}

A waste is any unwanted material intentionally thrown away for disposal (Oresanya, 1998). According to World Health Organization (WHO, 1984), wastes comprise countless different materials such as dust, food wastes, packaging in the form of paper, metal, plastic, or glass, discarded clothing, garden wastes, pathological and radioactive waste. When these wastes are discharged to the environment, they do not pose any risk to people or the environment (Hogson, 2004). A Municipal Solid Waste (MSW) therefore is any non-hazardous, solid waste from a combination of domestic, commercial and industrial sources. Examples of these wastes include natural materials such as clay, soil and rock, concrete, brick and demolition products. Ogwueleka (2009) defined it to include refuse from households, non-hazardous solid waste from industrial, commercial and institutional establishments (including hospitals), market waste, yard waste and street sweepings. Landfill is considered as one of the most common methods of waste disposal throughout the world due to its cost effectiveness and it involves dumping of waste in unused/unwanted sites (Bougioukou et al., 2005; El-Fadel et al., 1995). According to Porta et al. (2009) and Rushton (2003), landfill is defined as the dumping of waste in places precisely meant for such.

Bougioukou et al. (2005) stated that one of the most common waste disposal methods is landfilling where large volumes of municipal and industrial solid wastes are buried in landfills. In recent years, it has been discovered that the quality of ground water is being affected by a growing number of contaminants (Adeyemi et al., 2007). There are a number of environmental concerns associated with the disposal of municipal solid waste in landfills. Hazardous waste may pose an unreasonable risk to health, safety or property, especially those materials that are toxic, corrosive, reactive or ignitable. Disposal sites are capable of releasing large amounts of harmful chemicals to nearby water sources and air via leachate and landfill gas respectively (Alimba, 2006). According to Alimba et al. (2009), leachate can have an adverse impact on the environment when released in an uncontrolled manner. As humans we cannot do without generating waste. As a result, managing these generated wastes has been a world-wide challenge (Kadafa et al., 2013). Porta et al. (2009) reported that waste 
management which deals with generation, collection, processing, transport and disposal of solid waste is highly important for both ecological and communal reasons. It is very possible that being exposed to refuse dump would be disastrous on human behaviour and brain. However, it is so unfortunate that the less privileged are found living close to these dump sites. As a result, this present study will therefore assess the effect of landfill pollution on haematology and body weights of wild rats, Rattus rattus. The result will then give us an insight into the possible long-term effects of municipal solid waste landfill on humans.

\subsection{Methodology}

\subsection{Study site}

The study site is Abule-Egba landfill, located in Lagos, Nigeria (Figure 1 below). This Abule-Egba dump site is located on a 21-hectare habitable area and was open to the public for dumping of refuse in 1982. It has been used for municipal solid waste disposal for public and private waste management operators. The site manager indicated that an average of about 1,400 metric tonnes of waste is dumped at this site per day. The waste is discarded in an area adjacent to the only vehicular entrance to the site. Samples of leachates were collected from the landfill site and analysed for some standard physical and chemical properties and compared with FEPA and USEPA limits for safe disposal to surface water body (Table 1).

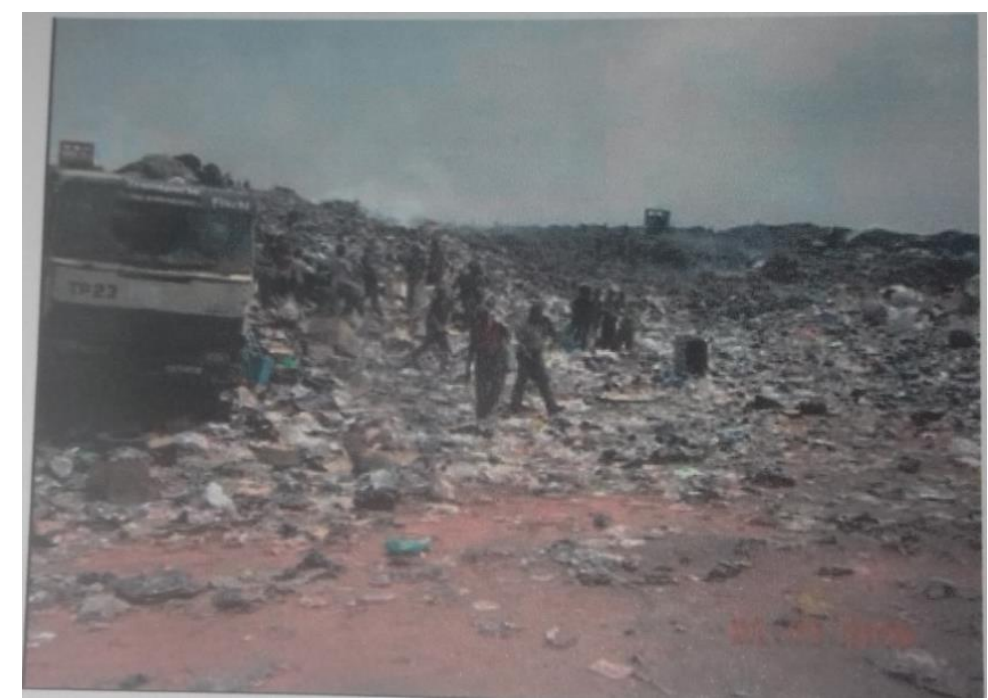

Figure 1: Dumping of waste at Abule-Egba landfills

\subsection{Experimental animal}

Twenty five (25) exposed wild rats (Rattus rattus) were collected from the dumpsite, while five (5) animal samples were captured from Iyana-Ipaja $(10 \mathrm{~km})$ from the neighbouring countries to serve as control.

\subsection{Weighing, dissection of rats and collection of blood samples}

At the beginning of the experiment, the body weight (BW) of each animal in the test group and control was measured using electronic analytical balance (Acculab USA, Model-vic-303). The liver, kidney, lungs, heart and spleen were removed through a central incision on the abdomen and weighed immediately. Blood samples were taken from the 25 exposed rats and five (5) controls through the ocular puncture using capillary tube. Samples collected were analysed with the Automated Haematological Analyzer, KX-21N (Sysmex) at the Lagos State University College of Medicine, Department of Haematology and Blood Transfusion. The blood parameters analysed were: Haematocrit (HCT/PCV), Haemoglobin (HGB), Red blood cells (RBC), Platelet Counts, Mean Corpuscular Volume (MCV), Mean Corpuscular Haemoglobin (MCH), Mean Corpuscular Haemoglobin Concentration (MCHC) and Differential White blood cell count: Neutrophil, Lymphocytes and Mixed cell ratio (ratio of the summation of Monocytes, Eosinophils and Basophils). 
Table 1: Heavy metals, Physical and Chemical characteristics of Leachates Samples from AbuleEgba landfills

\begin{tabular}{|l|l|l|l|}
\hline Parameters & Abule-Egba Landfill & FEPA & USEPA \\
\hline BOD + & 585 & 50 & - \\
\hline COD++ & 440 & - & 410 \\
\hline pH & 7.1 & $6-9$ & $6.5-8.5$ \\
\hline Hardness & 350 & - & $0-75$ \\
\hline Total Alkalinity & 490 & 250 & 20 \\
\hline Iron & 1.6 & 0.05 & 0.3 \\
\hline Sulphate & 60.50 & 20 & 250 \\
\hline Nitrate & 3.20 & - & 10 \\
\hline Ammonia & 8.4 & 0.01 & 0.02 \\
\hline Chloride & 480 & - & 250 \\
\hline Copper & 0.58 & 0.3 & 1 \\
\hline Total Dissolved Solid & 1.20 & 2000 & 500 \\
\hline Manganese & 1.0 & 0.5 & 0.5 \\
\hline Cadmium & 0.62 & 0.5 & 0.5 \\
\hline Lead & 1.1 & 0.01 & 0.015 \\
\hline
\end{tabular}

*All values are in $\mathrm{mg} / \mathrm{L}$ except $\mathrm{pH}+$ Biochemical Oxygen Demand ++ Chemical Oxygen Demand Federal Environmental Protection Agency (www.epa.gov/safe/mcl.html) *The FEPA/USEPA limits indicates safe disposal to surface water body

\subsection{Statistical analysis}

The mean values of data obtained were compared using students' test to determine significant difference between the control and the exposed rats. Statistical significance was accepted at $p<0.05$. Relative weights and Haematological values are expressed as means \pm standard deviation.

\subsection{Results and Discussion}

\subsection{Body weights and organ weights}

The mean and standard deviation of the body weights, liver, heart, lung, kidney and spleen of rats are shown in Table 2. The body weights of rats in the control group were significantly higher than the body weights of the exposed rats. The differences in body weights were considered based on the ratio of the organ weight to body weight. The relative weights of liver, hearts, lungs, heart and spleen were significantly higher $(p<0.05)$ in the rats that were exposed to landfill pollutants than the control group.

Table 2: Mean values of body weights and relative organ weights of control and exposed rats

\begin{tabular}{|l|l|l|}
\hline Parameters & Control & Exposed \\
\hline Body weight & $232.6 \pm 28.8$ & $167.6 \pm 126.8$ \\
\hline Liver & $4.0 \pm 0.1$ & $5.2 \pm 2.5$ \\
\hline Left Kidney & $0.3 \pm 0.1$ & $0.6 \pm 0.2$ \\
\hline Right Kidney & $0.3 \pm 0.1$ & $0.6 \pm 0.2$ \\
\hline Lung & $0.3 \pm 0.1$ & $1.1 \pm 0.4$ \\
\hline Heart & $0.4 \pm 0.1$ & $0.6 \pm 0.2$ \\
\hline Spleen & $0.4 \pm 0.1$ & $0.5 \pm 0.3$ \\
\hline
\end{tabular}

\subsection{Haematological parameters}

The blood haematological parameters are shown in Table 3. The haemoglobin content and haematocrit values showed decline in the animals that were exposed to municipal solid waste when compared with control values. The red blood cell (RBC) counts in the exposed rats showed no significant difference from those of the controls $(p>0.05)$. The total white blood cell (WBC) count showed variable values, but were found not significant. Haematological examination of rats did not reveal any statistically significant variations in the numbers of total WBC, platelets, amounts of Haemoglobin or levels of haematocrit between the control and exposed animals. 
Table 3: Mean values of full blood assay of wild rats

\begin{tabular}{|l|l|l|}
\hline Parameters & Control & Exposed \\
\hline White Blood cell $(\mathrm{WBC})\left(\mathrm{x} 10^{9} / \mathrm{l}\right)$ & $10.4 \pm 0.8$ & $8.9 \pm 5.8$ \\
\hline Lymphocyte $\left(\mathrm{x} 10^{9} / \mathrm{l}\right)$ & $7.7 \pm 0.7$ & $4.6 \pm 3.1$ \\
\hline Mixed $\left(\mathrm{x} 10^{9} / \mathrm{l}\right)$ & $1.1 \pm 0.3$ & $2.8 \pm 3.0$ \\
\hline Neutrophil $\left(\mathrm{x} 10^{9} / \mathrm{l}\right)$ & $1.6 \pm 0.3$ & $1.5 \pm 1.4$ \\
\hline Red Blood cell $(\mathrm{RBC})\left(\mathrm{x} 10^{12} / \mathrm{l}\right)$ & $7.0 \pm 0.5$ & $5.0 \pm 2.2$ \\
\hline Haemoglobin $(\mathrm{HB})(\mathrm{g} / \mathrm{dl})$ & $14.2 \pm 1.2$ & $10.0 \pm 4.1$ \\
\hline Packed Cell Volume, PCV $(\%)$ & $43.4 \pm 4.7$ & $32.0 \pm 13.9$ \\
\hline Platelet $(\mathrm{PLT})\left(\mathrm{x} 10^{9} / \mathrm{l}\right)$ & $391.6 \pm 22.4$ & $700.3 \pm 351.2$ \\
\hline Mean Corpuscular Volume $(\mathrm{MCV})(\mathrm{fL})$ & $54.9 \pm 2.6$ & $64.1 \pm 5.9$ \\
\hline Mean Corpuscular Haemoglobin $(\mathrm{MCH})(\mathrm{pg})$ & $21.8 \pm 0.8$ & $22.0 \pm 6.4$ \\
\hline Mean Corpuscular Haemoglobin Concentration (MCHC) $(\mathrm{g} / \mathrm{dl})$ & $35.7 \pm 5.2$ & $33.7 \pm 7.4$ \\
\hline
\end{tabular}

The observed low weights in the body weights of animals under study compared with the control may be associated with the high concentrations of pollutants in the leachate-contaminated landfills. The weights of rats exposed to leachate-contaminated landfills reduced significantly compared to control. However, the increase in weights observed by the organ weight of exposed rats compared to control may be due to inflammatory responses of organ tissues. Torres et al. (2006) also in their study observed changes in kidney weight which may reflect renal toxicity, tubular hypertrophy or chronic progressive nephropathy. The relatively low haemoglobin, PCV and RBC concentrations of the blood of the exposed rats observed in this study suggest that the pollutants of the leachate-contaminated groundwater can directly or indirectly destroy blood cells and lower the haemoglobin concentrations. Islam et al. (2004) gave a report that changes observed in haematological parameters like haemoglobin, packed cell volume and red blood cells usually determines stress associated with environmental, nutritional and pathological factors. They also noted that these changes can be associated with anaemia.

Increased platelets concentration observed in the blood of rats exposed to leachate-contaminated landfills may be attributed to the presence of heavy metals amongst others (Table 1). These rats must have ingested high levels of metals like lead (Kadafa et al., 2013). Bioaccumulation of metals like cadmium and lead in the liver and kidneys of small mammals in landfill sites and polluted areas have been reported (Torres et al., (2006). Oladele et al. (2013) in their study observed that the white blood cells, total proteins and differential counts were significantly high in mice exposed to paint effluents. This was probably due to the heavy metals contained in the paint effluents. Also, Alimba et al. (2009) observed significantly high levels of metals such as lead, cadmium, mercury and copper in the two municipal wastes studied when compared with FEPA and USEPA limits. Further in their study, they opined that the leachate constituents including metals are capable of suppressing the activities of lymphoid tissues and haematopoietic cells in the bone marrow of rats. Amin et al. (2016), in their haematological studies revealed that the values of TEC (total erythrocyte count), ESR (erythrocyte sedimentation rate), $\mathrm{Hb}$ (hemoglobin) and PCV (packed cell volume) were decreased significantly in mice exposed to textile dye wastewater. Also, Bakare and Wale-Adeyemo (2004) stated that the land fill of Aba-Eku led to mortality of domestic animals and destruction of crops as a result of exposing the test organisms to contaminated water by the landfill leachate.

\subsection{Conclusion}

The findings in this study indicated that landfills from Abule-Egba contained toxic constituents capable of inducing haematological changes in study organism; wild rats (Rattus rattus). As a result, leachate generation at the study site is of health concern to humans. There is therefore a need for proper disposal of wastes.

\section{References}

Adeyemi, O., Oloyede, O. B., and Oladiji, A.T. (2007). Physicochemical and microbial characteristics of leachates-contaminated groundwater. Asian journal of Biochemistry, 2(5), pp. 343-348

Alimba, C. G., Bakare A. A. and Arinola, G. O. (2009). Effects of municipal solid waste leachate on leucocyte and differential counts in rat. Global Journal of Environmental Research, 3(3), pp. 205-210. 
Alimba, C. G., Bakare A. A. and Latunji, C. A. (2006). Municipal landfill leachates induced chromosomes aberrations in rat bone marrow cells. African Journal of Biotechnology, 5(22), pp. 2053-2057.

Amin T., Afrin M., Haque, Z., and Islam, M. R. (2016). Toxicity of textile dye wastewater on liver of mice. Journal of Agriculture and Veterinary Science (IOSR-JAVS, 9(1), pp. 29-34.

Bakare, A. A. and Wale-Adeyemo, A. R. (2004). The mutagenic and cytotoxic effects of leachates from domestic solid wastes and Aba- Ekuland fill, Nigeria on Allium cepa. Nature Environment Pollution Technology, 3(4), pp. 445-462.

Bougioukou, G. G., Papadopoulou, M. P., and Karatazas, G. P., (2005). Proceedings of the $9^{\text {th }}$ International conference on Environmental Science and Technology, Rhodes Island, Greece, 1-3 September, 2005

El-Fadel, M., Findikakis, A. N. and Leckie, J. O. (1997). Environmental impacts of solid waste landfilling. J.Environ.Management, 50, pp. 1-25. doi:10.1006/jema.1995.0131.

FEPA (1991). Guidelines and standards for environmental pollution control in Nigeria. Federal Environmental Protection Agency, Lagos, Nigeria. 250pp.

Hogson, E. (2004).Water and soil pollutants. In: A textbook of modern toxicology. $3^{\text {rd }}$ ed. John Wiley and sons Inc. New Jersey, U.S.A pp. 42-57.

Islam, M.S., Lucky, N.S., Islam, M.R., Ahad, A., Raham, M.M., et al. (2004). Haematological parameters of fayoumi, Assil and local chickens reared in Sylhet region in Bangladesh. Int. Journal Poultry Science, 3(2), pp. 144-147.

Kadafa, A.Y., Latifa, A., Abdullahi, H. S. and Suleiman, W.A. (2013). Comparative assessment of the municipal solid waste management services. Natural Science, 11(6), pp. 154-164.

Ogwueleka, T. C. (2009).Municipal solid waste characteristics and management in Nigeria. Iran. J. Environ. Health. Sci. Eng., 6(3), pp. 173-180.

Oladele, E. O., Odeigah, P. G. C. and Yahaya, T. (2013). Hematotoxicity of paint effluent on Swiss Albino mice. The Pacific Journal of Science and Technology, Akamai University. 14(2), pp. 397-404.

Oresanya, O. (1998). Waste control Measures and Responsibility of a waste manager within the framework of recent management methods and development in municipal and industrial wastes. Paper presented at the workshop on Effective Waste management in Nigeria organized by the Nigerian society of Engineers, Lagos. April.

Porta D., Milani S., Lazzarino A. I., Perucci C. A. and Forastiere, F. (2009). Systematic review of epidemiological studies on health effects associated with management of solid waste. Environ. Health, 8(60), pp. 1-14.

Rushton, L. (2003). Health hazards and waste management. Br. Med Bull 68: pp.183-197.

Torres, J.J., Peig, C. and Borras, M. (2006). Cadmium and lead concentrations in Skrjabinotaenia lobata (Cestoda: Catenotaeniidae) and in its host, Apodemus sylvaticus (Rodentia Muridae) in the urban dumping site of Garraf (Spain). Environ. Pollution, 143, pp. 4-8.

USEPA (2001). Lead safe-yards. U.S Environmental Protection Agency, Wash.DC. EPA/625/r00/012. www.epa.gov/empact

World Health Organization (1984). Solid waste Management in South-East Asia. WHO House, New Delhi, India. 